\title{
Partial Characterization of an Inulinase Produced by Aspergillus japonicus URM5633
}

\author{
Anna Carolina da Silva ${ }^{1}$, Alana Emilia Soares de França Queiroz ${ }^{1}$, Tatiana Souza Porto ${ }^{1,2}$, \\ Michele Rigon Spier ${ }^{3}$, Carlos Ricardo Soccol ${ }^{3}$, Ana Lúcia Figueiredo Porto ${ }^{2}$, Cristina \\ Maria Souza-Motta ${ }^{4}$ and Keila Aparecida Moreira ${ }^{1,2^{*}}$ \\ ${ }^{1}$ Unidade Acadêmica de Garanhuns; Universidade Federal Rural de Pernambuco; Av. Bom Pastor, s/n; 55296-901; \\ Garanhuns - PE - Brasil. ${ }^{2}$ Laboratório de Tecnologia de Bioativos; Departamento de Morfologia e Fisiologia \\ Animal; Universidade Federal Rural de Pernambuco; Av. Dom Manuel de Medeiros s/n; 52171-900; Recife - PE - \\ Brasil. ${ }^{3}$ Departamento de Engenharia de Bioprocessos; Universidade Federal do Paraná; Campus Politécnico \\ 80060-000; Curitiba - PR - Brasil. ${ }^{4}$ Departamento de Micologia; Universidade Federal de Pernambuco; Av. Prof. \\ Nelson Chaves s/n; 50670-420; Recife - PE - Brasil.
}

\begin{abstract}
Enzymes obtained by fermentation processes offer a number of advantages and have been widely researched and used throughout the world. This study aimed to partially characterise an inulinase produced from palm and cassava peel. The enzyme was produced via the solid-state fermentation of Aspergillus japonicus URM5633. The optimal temperatures were $50^{\circ} \mathrm{C}$ and $55^{\circ} \mathrm{C}$, and the optimal $\mathrm{pH}$ values were 5.2 and 3.4 for inulinase fermentatively produced from palm and cassava peel, respectively. The thermostability measurements for inulinase produced in palm showed that the relative activity remained below $100 \%$ until 30 minutes of stability for all temperatures, but reached $106.8 \%$ at a temperature of $50^{\circ} \mathrm{C}$ after 60 minutes. Inulinase from the crude extract of cassava peel was pH stable and only decreased to $55 \%$ of the maximal activity over the course of the assay, suggesting that this enzyme can be used in inulinase production and can be utilized in food industries.
\end{abstract}

Key words: inulinase, characterisation, solid-state fermentation, Aspergillus japonicus

\section{INTRODUCTION}

Inulinase $(2,1-\beta-D$-fructan fructanohydrolases EC 3.2.1.7) hydrolyses inulin into practically pure fructose (Cazetta et al. 2010) and provides an excellent alternative for the production of fructose syrup (Vandamme and Derycke 1983a; Treichel et al. 2009). The polysaccharide inulin has physicochemical properties that can replace both sugar and fat in various food products, and it can be classified as a functional food, or prebiotic, as it confers beneficial physiological effects on human metabolism (Roberfroid 2002). Fructose formation from inulin offers an advantage as it involves only a single enzymatic step, which yields up to $95 \%$ fructose (Pandey et al. 2000).

The syrup can be depolymerised by two enzymes, an exoinulinase, which can release fructose units from the far end of the molecule of inulin, and an endoinulinase, which acts at random on the internal couplings of the molecular syrup, releasing inulin-triose, inulin-tetraose and inulinpentose as the main products (Jing et al. 2003). Solid-state fermentation (SSF) may be defined as a

*Author for correspondence: moreiralab@yahoo.com.br 
fermentation process where the microorganisms grow in solid substrates with low water concentration. Many studies on the application of SSF are focused in adding value to agroindustry residues, which have been extensively used as a physical support or source of nutrients in SSF (Mazutti et al. 2006). The enzymes produced by fermentation processes offer a number of advantages and have been widely researched and used throughout the world. The application of enzymes in food technology is a viable alternative because the process consumes little energy, improves the quality of various products and causes minimal environmental impact (Soccol and Vandenberghe 2003). The industrial application of enzymes is determined by enzyme specificity, activity, stability (storage and use), availability and production costs. Enzymes are evaluated in industry by many factors, including the following: the concentration at which the enzyme must be produced; the nature of the enzyme's substrate; the required concentrations of the necessary co-factors and/ or allosteric effectors; the presence, concentration and types of inhibitors; and the optimal ionic potential, $\mathrm{pH}$, temperature and reaction time (Moreira et al. 2003).

\section{MATERIALS AND METHODS}

\section{Microorganism and Agroindustry Residues Aspergillus japonicus URM5633 was obtained from the collection of URM at the Department of Mycology, Federal University of Pernambuco. The palm and cassava peel were obtained from local farmers in Garanhuns/PE, Brazil.}

\section{Production of Inulinase}

Fermentations were performed in Erlenmeyer flasks $(125 \mathrm{~mL})$ with $10 \mathrm{~g}$ of each substrate (either cassava peel or palm). Fermentations were performed at $28^{\circ} \mathrm{C} \pm 2$ for 120 hours then stopped to perform the enzymatic extraction.

\section{Enzyme Extraction}

The enzyme was extracted after 120 hours of fermentation by adding $25 \mathrm{ml}$ of sodium acetate buffer $(20 \mathrm{mM}, \mathrm{pH} 6.0)$ to every $10 \mathrm{~g}$ of fermented medium, then incubating the mixture in a water bath at $32^{\circ} \mathrm{C}$ for a period of 1 hour and filtering through a Whatman filter (No. 01).

\section{Determination of Reducing Sugars}

To determine the sugars in the samples, we used the dinitrosalicylic acid (DNSA) method (Miller 1959). We added $1000 \mu \mathrm{L}$ of the reactive DNSA reagent to $100 \mathrm{~mL}$ of sample, placed the sample in boiling water for 10 minutes, and then took measurements with a spectrophotometer set to 570 $\mathrm{nm}$. The calibration curve was made from a standard solution of fructose (0 to $5 \mathrm{mg} \mathrm{mL}^{-1}$ ).

\section{Inulinase Activity}

The enzymatic assays were conducted according to a procedure by Kochhar et al. (1999). First, 80 $\mu \mathrm{L}$ of the inulin solution at $1 \%(\mathrm{w} / \mathrm{v})$ was dissolved in $0.1 \mathrm{M}$ sodium acetate buffer ( $\mathrm{pH} 4.8$ ). The $20 \mu \mathrm{L}$ sample was incubated at $37^{\circ} \mathrm{C}$ for 15 minutes. After this period, the reaction was stopped by the addition of $1 \mathrm{~mL}$ of the 3,5- DNSA reagent (Miller 1959), and the resulting reducing sugar was monitored. Fructose was used as a standard. One unit of inulinase (U) was defined as the amount of enzyme that produced $1 \mu \mathrm{mol} \mathrm{min}{ }^{-1}$ of fructose under the assay conditions described above.

\section{Effect of pH on Enzyme Activity}

The optimum $\mathrm{pH}$ for the enzymatic activity of inulinase was determined using different buffers at $0.2 \mathrm{M}$. The following buffers were used to test appropriate $\mathrm{pH}$ values, which appear in parentheses after the buffer composition: glycine $\mathrm{HCl}$ buffer ( $\mathrm{pH} 3.0,3.4$ and 3.6), citrate buffer $(\mathrm{pH}$ 3.4, 3.8, 4.0, 4.4, 4.8 and 5.2), phosphate buffer $(\mathrm{pH} 4.8,5.2,5.6$ and 6.0) and sodium acetate buffer ( $\mathrm{pH} 4.4,4.8$ and 5.2). The determination of enzyme activity was performed as described previously.

\section{Effect of Temperature on Enzyme Activity}

The optimum temperature was determined by measuring the enzymatic activity of the crude extract on inulin solutions (1\% w/v) prepared in $0.1 \mathrm{M}$ sodium acetate buffer $(\mathrm{pH} 4.8)$; the enzymatic activity was monitored at $25,37,45,50$ and $55^{\circ} \mathrm{C}$.

\section{Stability of Enzyme at pH}

The $\mathrm{pH}$ stability was measured by subjecting the extracts to buffered conditions at different $\mathrm{pH}$ values (glycine- $\mathrm{HCl}$ at $\mathrm{pH} 3.0$, citrate at both $\mathrm{pH}$ 3.4 and $\mathrm{pH} 4.0$, acetate at $\mathrm{pH} 4.8$ and citrate and phosphate at $\mathrm{pH}$ 5.2) before starting the enzymatic reaction. Aliquots were used to determine the 
activity of inulinase at time intervals of $30,60,90$ and 120 minutes.

\section{Enzyme Stability to Temperature}

To determine the heat stability, the enzyme was subjected to temperatures of $30,40,50,60$ and $70^{\circ} \mathrm{C}$. Aliquots were retained to determine the specific activities at time intervals of $30,60,90$ and 120 minutes. The samples of each interval were subjected to analytical determinations. All tests were performed in triplicate. The minimum significant differences for the Tukey test was $\mathrm{P}<0.05$.

\section{RESULTS AND DISCUSSION}

The partial characterisation of inulinase enzyme extracts from palm showed that the optimal $\mathrm{pH}$ (Fig. 1A and B) and temperature (Fig. 2) were 5.2 (sodium acetate buffer, $0.2 \mathrm{M}$ ) and $37^{\circ} \mathrm{C}$, respectively. The enzymatic extract obtained from the fermentation of cassava peel showed that the optimal pH (Fig. 1 B) and temperature (Fig. 2) were 3.4 (glycine- $\mathrm{HCl}$ buffer, $0.2 \mathrm{M}$ ) and $55^{\circ} \mathrm{C}$, respectively.
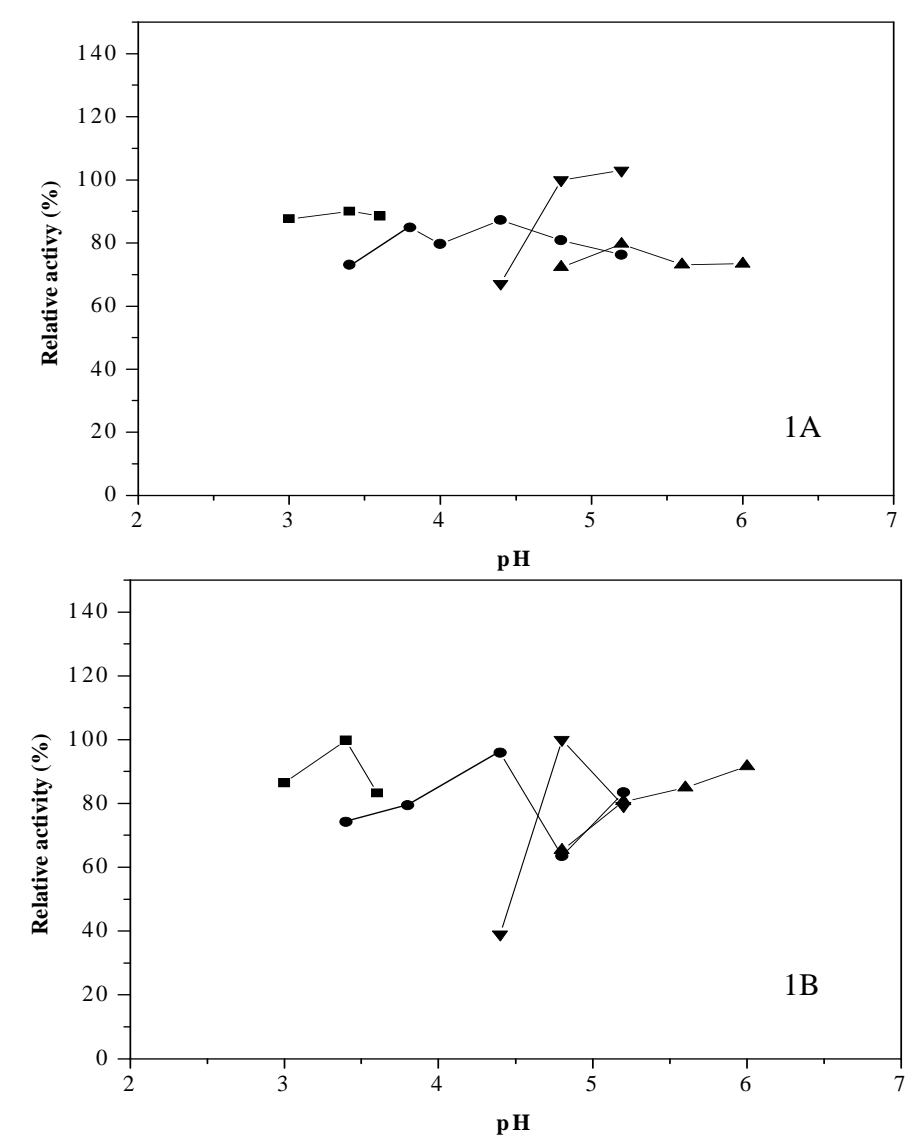

Figure 1 - Effect of $\mathrm{pH}$ on the relative specific inulinase activity of A. japonicus URM5633 from palm (A) and cassava peel (B). Buffers - ( $\mathbf{a})$ glycine $\mathrm{HCl},(\bullet)$ citrate, $(\boldsymbol{\nabla})$ sodium acetate and $(\boldsymbol{\Delta})$ citrate phosphate. Mean of three repetitions. Minimum significant differences for the Tukey test $(\mathrm{P}<0.05)$.

However, the results in the literature show that optimal activity of inulinase produced by $A$. niveus 4128URM occurs between a $\mathrm{pH}$ range of 4.0 and 7.0 and at a temperature between $45^{\circ} \mathrm{C}$ and $50^{\circ} \mathrm{C}$ (Souza-Motta et al. 2005). The enzymes produced by different substrates display different behaviours across the tested temperature range (Fig. 2). The enzyme produced by the fermentation of palm has a relative activity value that increases from 25 to $35^{\circ} \mathrm{C}$ and peaks at $50^{\circ} \mathrm{C}$ before sharply declining at 
$55^{\circ} \mathrm{C}$, where it has the lowest activity. The enzyme produced by the fermentation of cassava peel has activity values that increase until a temperature of $45^{\circ} \mathrm{C}$, decline at $50^{\circ} \mathrm{C}$, then reach a maximum at $55^{\circ} \mathrm{C}$.

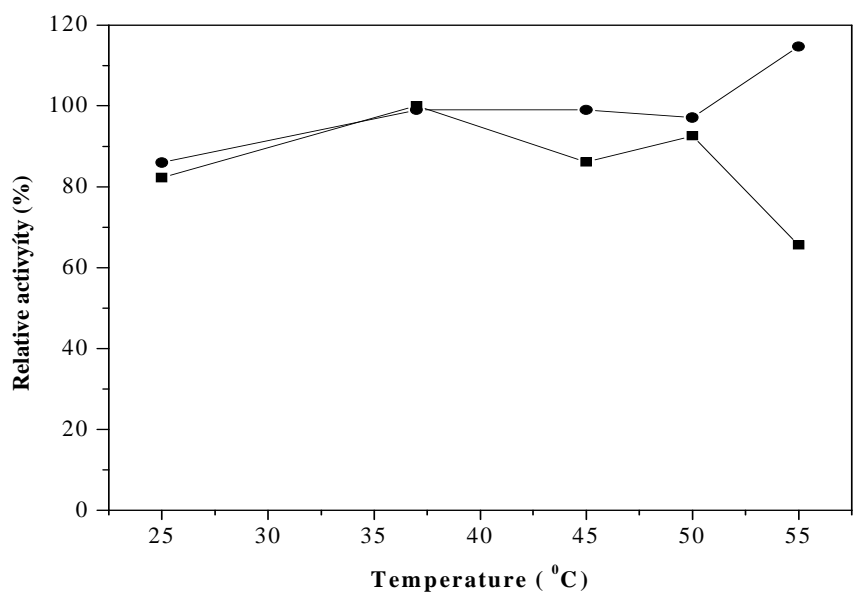

Figure 2 - Effect of temperature on the relative specific inulinase activity of A. japonicus URM 5633 from palm ( $\bullet$ ) and cassava $(\bullet)$ as substrates. Mean of three Repetitions. Minimum significant differences for the Tukey test $(\mathrm{P}<0.05)$.

Some species of Aspergillus produce inulinases with maximum activity at higher temperatures. For example, the inulinase from A. niger 245 has optimal activity at $60^{\circ} \mathrm{C}$ (Cruz et al. 1998). However, temperatures above $55^{\circ} \mathrm{C}$ may disable some inulinases that are produced by fungi (Vandamme and Derycke 1983b). The stability of inulinase from palm was measured with respect to temperature, and the relative activity remained below $100 \%$ up to 30 minutes at all temperatures

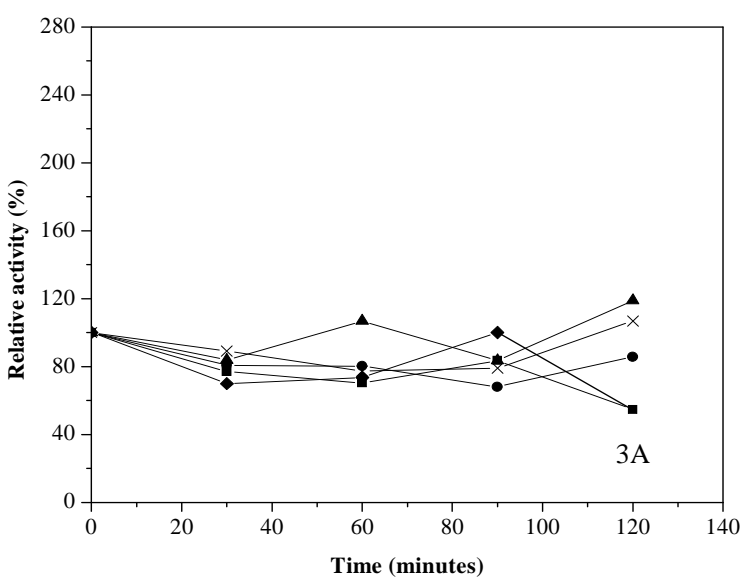

(Fig. 3A). At a temperature of $50^{\circ} \mathrm{C}$, the relative activity reached $106.8 \%$ after 60 minutes of stability; the lowest relative activity, $54.6 \%$, was measured at $30^{\circ} \mathrm{C}$ after 120 minutes of stability. After 120 minutes of stability at $50^{\circ} \mathrm{C}$, the relative activity reached $118.9 \%$. The enzyme in the crude extract of cassava peel (Fig. 3B) remained above $100 \%$ relative activity for all times and temperatures tested, reaching a $276.5 \%$ relative activity at $70^{\circ} \mathrm{C}$ after 90 minutes.

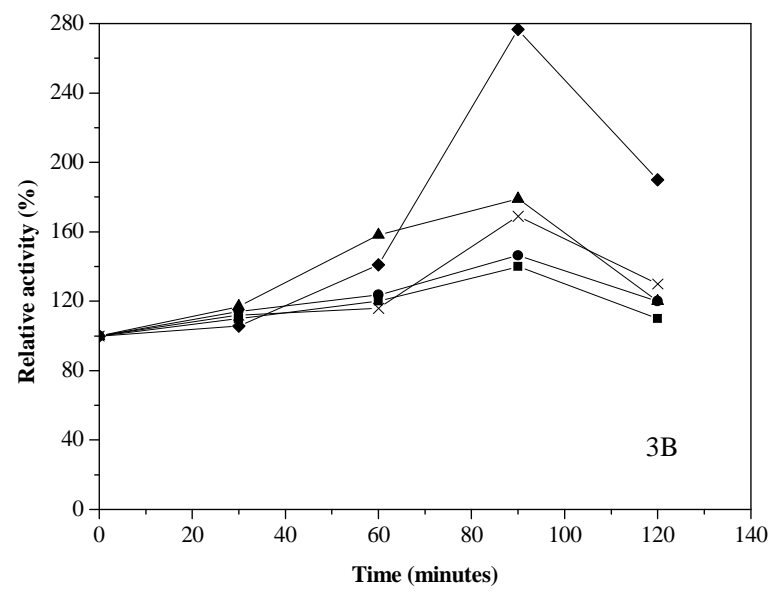

Figure 3 - Thermal stability of inulinase produced by A. japonicus 5633URM in palm (A) and cassava (B). Temperatures $-30^{\circ} \mathrm{C}(\boldsymbol{\bullet}), 40^{\circ} \mathrm{C}(\bullet), 50^{\circ} \mathrm{C}(\boldsymbol{\Delta}), 60^{\circ} \mathrm{C}(\times)$ and $70^{\circ} \mathrm{C}(\bullet)$. 
When analysing the stability of the enzyme at different $\mathrm{pH}$ values, it was noted that the inulinaseproduced from palm (Fig. 4A) remained below $100 \%$ relative activity at 120 minutes in the glycine $\mathrm{HCl}$ buffer ( $\mathrm{pH} 3.0,0.2$ $\mathrm{M})$ and the sodium acetate buffer $(\mathrm{pH} \mathrm{4.8,0.2}$ $\mathrm{M})$. There is a residual activity of $123.8 \%$ for the citrate buffer ( $\mathrm{pH} 3.4,0.2 \mathrm{M}$ ) at 60 minutes and residual activities of $226 \%$ and $448 \%$ for citrate buffer ( $\mathrm{pH} 4.0,0.2 \mathrm{M}$ ) and phosphate and citrate buffer ( $\mathrm{pH} 5.2,0.2 \mathrm{M}$ ), respectively, after 120 minutes.
The enzyme in the enzymatic extract of cassava peel (Fig. 4B) had a relative activity of more than $100 \%$ in glycine buffer $(\mathrm{pH} 3.0,0.2 \mathrm{M})$ and citrate buffer ( $\mathrm{pH} 3.4$ or $4.0,0.2 \mathrm{M}$ ), but a relative activity below $100 \%$ in sodium acetate buffer $(\mathrm{pH} 4.8,0.2 \mathrm{M})$ and phosphate and citrate buffer ( $\mathrm{pH} 5.2,0.2 \mathrm{M}$ ) after 30 minutes of stability. At 60 and 90 minutes, the stability remained below $100 \%$ under all conditions, with the lower activity of $54.8 \%$ for the citrate phosphate buffer after 60 minutes of stability.
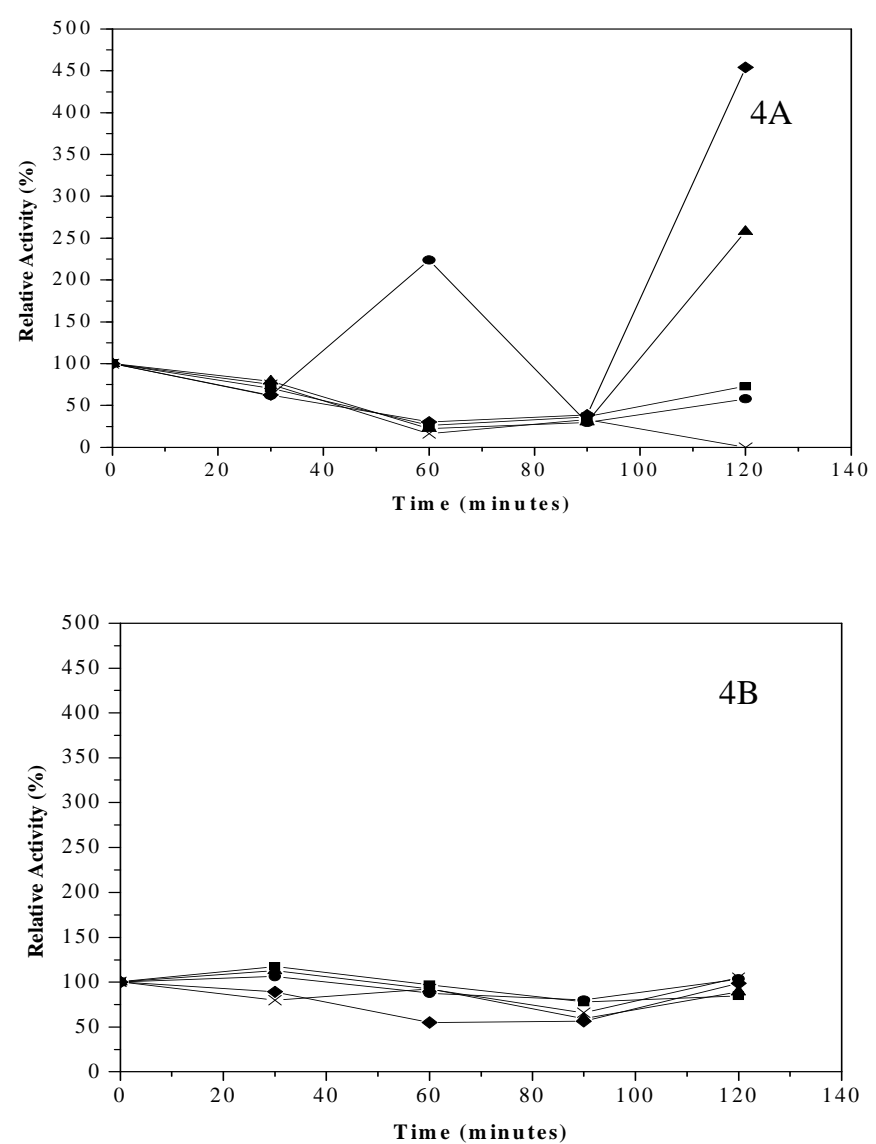

Figure 4 - Effect of $\mathrm{pH}$ on the stability of inulinase produced from palm (4A) and cassava (4B). Buffers - glycine-HCl pH $3.0(\boldsymbol{\bullet})$, citrate $\mathrm{pH} 3.4(\bullet)$ and $4.0(\boldsymbol{\Delta})$, sodium acetate $\mathrm{pH} 4.8$ $(\times)$ and citrate phosphate $\mathrm{pH} 5.2(\bullet)$. 


\section{CONCLUSIONS}

The results above confirm that the action of the inulinase can vary significantly depending on the substrate used to produce the enzyme. Enzyme produced from palm and cassava peel displayed different parameters, such as the optimal temperature and $\mathrm{pH}$, two factors of great importance for enzymes with potential use in biotechnological processes. The inulinase produced in this work has great potential to be used in the fermentation industry due to the impressive values of relative activity.

\section{ACKNOWLEDGMENTS}

The authors are grateful to FACEPE, CNPq and FINEP.

\section{REFERENCES}

Cazetta ML, Monti R, Contiero J. Effects of culture conditions on the production of inulinase by Kluyveromyces marxianus. Braz. Arch. Biol. Technol. 2010; 53: 701-707.

Cruz VD, Belote JG, Belline MZ, Cruz R. Production and action pattern of inulinase from Aspergillus niger-245: Hydrolysis of inulin from several sources. Rev. Microbiol.1998; 29: 4.

Jing W, Zhengyu J, Bo J, Augustine A. Production and separation of exo- and endoinulinase from Aspergillus ficuum. Process. Biochem. 2003; 39: 511.

Kochhar A, Gupta AK, Kaur N. Purification and immobilisation of inilinase from Aspergillus candidus for producing fructose. J. Sci. Food Agri. 1999; 549554.
Mazutti M, Bender JP, Treichel H, Di Luccio M. Optimization of inulinase production by solid-state fermentation using sugarcane bagasse as substrate. Enzyme Microb. Technol. 2006; 39: 56-59.

Miller GL. Use of dinitrosalicylic acid reagent for determination of reducing sugar. Anal. Chem. 1959; 31: 426-429.

Moreira KA, Porto TS, Texeira MFS, Porto ALF, Lima Filho JL. New alkaline protease from Nocardiopsis sp.: partial purification and characterization. Process Biochem. 2003; 39: 67-72.

Pandey A, Soccol CR, Nigam P, Soccol VT. Biotechnological potential of agro-industrial residues: sugar-cane bagasse. Bioresoure Technol. 2000; 74: 69-80.

Roberfroid MB. Functional food concept and its application to prebiotics. Digest Liver. 2002; 34: 105109.

Soccol CR, Vandenberghe LPS. Overview of applied solid-state fermentation in Brazil. Biochem. Eng. J. 2003: 13: 205-218.

Souza-Motta CM, Cavalcanti MAQ, Porto ALF, Moreira KA, Lima Filho JL. Aspegillus niveus Blochwitz 4128URM: new source for inulinase production. Braz. Arch. Biol. Technol. 2005; 48: 343 350.

Treichel H, Mazutti M, Maugeri Filho F, Rodrigues MI. Technical viability of the production, partial purification and characterisation of inulinase using pretreated agroindustrial residues, Bioproc. Biosyst. Eng. 2009; 32: 425-433.

Vandamme EJ, Derycke DG. Microbial inulinases: Fermentation process, properties and applications. Advances Appl. Micróbiol. 1983; 29: 139-176. 